\title{
Comparative Assessment of Neuro-Cognitive Impairments Among Patients with Brain Tumor and Healthy Adults
}

\section{Beyin Tümörlü ve Sağllkh Yetişkinler Arasında Nörokognitif Bozukluklarm Karşılașturmalı Değerlendirmesi}

\author{
Afsaneh ZARGHI ${ }^{1}$, Alireza ZALI ${ }^{2}$, Mehdi TEHRANIDOST ${ }^{1}$, Mohammad Reza ZARINDAST ${ }^{1}$, \\ Farzad ASHRAFI ${ }^{2}$, Mojtaba KHODADADI ${ }^{3}$ \\ ${ }_{1}^{1}$ Institute for Cognitive Science Studies, Department of Cognitive Sciences, Tehran, Islamic Republic of Iran \\ ${ }_{2}^{2}$ Functional Neurosurgery Research Center of Shahid Beheshti University of Medical Sciences, Department of Neuroscience, Tehran, \\ Islamic Republic of Iran \\ ${ }^{3}$ Sina Institute of Behavioral Sciences, Department of Psychology, Tehran, Islamic Republic of Iran
}

Correspondence address: Afsaneh ZARGHI / E-mail: Dr.a.zarghi@hotmail.com

\section{ABSTRACT}

AIM: Most brain tumor patients encounter cognitive impairments. Coping with such challenges is intolerable for them. Objective: This study tries to determine the diagnostic role of cognitive tests, CPT, Stroop and TOL, in assessing neuro-cognitive impairments among patients with brain tumor and healthy participants.

MATERIAL and METHODS: A cross-sectional study was done on a sample of 15 to 65 years old of 84 brain tumor patients and 84 healthy Iranians. Participants of both groups were physically and mentally examined and approved by neurosurgeons, neurologists and psychiatrists. By completing the questionnaires, they all entered the study and were referred to the neuroscientist for performing the tests.

RESULTS: According to CPT, Stroop and TOL tests, the performance of both groups was significantly regarding about age, sex and education variables $(P<0.05)$.

CONCLUSION: Brain tumor patients in comparison to healthy participants met more cognitive changes on sustained, selective attention and planning. Therefore, diagnosis and assessment of these cognitive changes before and after the surgery can help rehabilitating patients' brains and improve their lives quality.

KEYWORDS: Neuro-cognitive impairments, Brain tumor, Healthy adults

öz

AMAÇ: Çoğu beyin tümörü hastası kognitif bozukluklar yaşar. Bu tür zorluklarla başa çıkmak bu hastalar için tolere edilemez bir durumdur. Bu çalışma, beyin tümörü olan hastalar ve sağlıklı kişiler arasında nörokognitif bozuklukları değerlendirmek için CPT, Stroop ve TOL kognitif testlerinin diagnostik rolünü belirlemeye çalışmaktadır.

YÖNTEM ve GEREÇLER: Bu çalışma, 15 - 65 yaşında 84 beyin tümörü hastası ve 84 sağlıklı İranlı üzerinde yapılmıştır. Her iki grubun katılımcıları beyin cerrahları, nörologlar ve psikiyatristler tarafından fiziksel ve zihinsel olarak incelenip onaylanmışlardır. Sonra soru formlarını doldurarak çalışmaya katılmış ve testlerin yapılması için bir nörolojik bilimler uzmanına gönderilmişlerdir.

BULGULAR: CPT, Stroop ve TOL testlerine göre iki grup arasında yaş, cinsiyet ve eğitim değişkenleri bakımından önemli performans farkı bulunmuştur $(P<0,05)$.

SONUÇ: Sağlıklı katılımcılara göre beyin tümörü hastalarında uzun süreli ve seçici dikkat ve planlama konusunda daha fazla kognitif değişiklik bulunmuştur. Bu nedenle, cerrahi öncesinde ve sonrasında bu kognitif değişikliklere tanı koyma ve değerlendirme bu hastaların beyin rehabilitasyonuna ve yaşam kalitelerini arttırmaya yardımcı olabilir.

ANAHTAR SÖZCÜKLER: Nörokognitif bozukluklar, Beyin tümörü, Sağlıklı yetişkinler 


\section{INTRODUCTION}

Recent neuro-cognitive investigations stressed that the incidence of tumors has increased in the last 30 decades (23). Brain tumors are a group of neoplasm with unique biology, diagnosis and treatment. Cognitive impairments are noticeable amongst brain tumor patients as significant deficits which arise through complicated processes $(41,43)$; half of all brain tumor patients are faced with emotional and cognitive disorders at some stage of their disease $(20,37,57)$. Coping with the emotional and cognitive challenges of brain tumors is a difficult task for patients with brain tumor. Some previous studies have underlined cognitive aspects over emotional ones (63); whereas others have focused on the quality of life, instead of emotional and cognitive aspects of brain tumor patients (29). In this regard, neurosurgeons, neurologists, psychiatrists and neuroscientists have tried to improve the patient's condition. Currently, researchers are of the view that the recognition and rehabilitation of cognitive impairments may possibly help to increase life expectancy and improve the lifestyle and quality of life of brain cancer patients $(4,19$, $30,60)$. The most prevalent cognitive impairments amongst brain tumor patients include disorders in attention, executive functions, visuo-spatial and constructional skills, sensory perceptual functions, language, memory and intellectual functions (35). Cognitive impairments depend on the location and type of tumor, as well as the treatment and other changes like fatigue and anxiety during sleep. $(14,65)$. These problems can occur during the cancer diagnosis and treatment period, and also during survival. Executive function attributed to selfcontrol behaviors and attention is a set of complicated neural processes controlled by the dispersed neural net, including the cortical and sub-cortical regions such as the frontal cortex and basal ganglia-thalamic-cerebellar connections. (40). Some researchers have considered the effect of dependent demographic agents and medical variables on neurocognitive impairments and feel that sustained and selective attention, information processing rate and executive functions in brain tumor patients are reversible. Previous studies have reported that targeted therapies may delay cognitive decline; however, these results require confirmation in future studies. (28). Considering these issues, cognitive tests such as the Continuous Performance Test (CPT), Stroop and Tower of London (TOL) tests are quick and frequently used measures for assessing neuro-cognitive impairments in executive function and attention amongst patients and healthy individuals. CPT generates quantitative data relating to the participant's ability in sustaining attention for a period of time; and can be used to assess cognitive impairments in brain tumor patients. Studies in brain tumor patients and healthy individuals using different versions of the CPT have shown that the results of the CPT can be influenced by harm or impairments to brain function, which can be affected in various diseases (40). The Stroop test is a quick and commonly used measure for assessing dysfunction in selective attention and cognitive flexibility $(48,52)$. The response of participants to target stimuli, whether the distracting items exist or not, can be an appropriate method to assess selective attention. The Stroop test may also be useful to investigate cognitive inhibitory processes. The TOL test can recognize unexpected impairments to the planning processes of frontal lobe (27, 58). Although these three tests have been used to assess cognitive impairments in a variety of studies by many researchers, our current investigation has its own novelty ( 1 , $9,13,25,31-34,38,39,42,44,45,47,50,53,55,56,61,64)$. As previously discussed, patients with brain tumor are faced with dysfunctions in sustained and selective attention and planning, and therefore the computerized CPT, Stroop and TOL tests were regarded as trustworthy tools for assessing cognitive impairments in the present study. Comparison of cognitive disorders between brain tumor patients and healthy individuals can help to diagnose the patient's risks to prevent, cure, recognize and rehabilitate them (35). This study was accomplished through the goal of assessing neurocognitive impairments among patients with brain tumor and healthy participants comparatively based on the mentioned authentic and valid tests.

\section{MATERIAL and METHODS}

\section{Subjects}

A cross-sectional comparative assessment of neuro-cognitive impairments was conducted during 6 months of study from May to September 2010, among an Iranian study population of 84 brain tumor patients 15 to 65 years old and 84 healthy participants with a mean age of $46 \pm 3$ years at the Neuroscience Department of Functional Neurosurgery Research Center (FNRC) of Shohada Hospital, Tehran, Iran. Healthy participants were referred to FNRC through a public recall. Brain tumor patients were from hospital in-patients who were all selected through simple random sampling. All participants were physically and mentally with the help of reliable neurosurgeons, neurologists and psychiatrists based on MRI, CT and stereotaxis to ensure the absence of any other diseases. The ongoing study was also approved by the Shahid Beheshti University. Before research participants enter the study, it was necessary to complete the informed consent and demographic questionnaire. Out of the total number of patients, 42 entered the study before and after surgery, and 42 before and after stereotaxis. Inclusion criteria were as follows: to be within the age range of 15 to 65 years, an inhabitant of Tehran, right-handed, Persian language speaker, lacking any history of neural and mental disease, surgery and medicine consumption. Exclusion criteria were not being in the age range of 15 to 65 years, not an inhabitant of Tehran, left-handedness, not Persian language speaker, having any history of neural and mental disease, and surgery and medicine consumption.

\section{Procedure}

In the current study, sustained, selective attention and planning were evaluated through CPT, Stroop and TOL tests, respectively. In all forms of the CPT test, the examinee has to pay attention to a set of quite simple stimuli, visual or 
auditory (only visual stimulus is present in this test). Then, at the appearance time of the target stimulus, the subject presses a button to provide the answer. This test should occur in a suitable place. Also, the performance conditions of the test must be observed psychologically. The purpose is that the examinee applies his maximum capacity and performs with the best speed. In this test, totally 150 stimuli are presented; among which $20 \%$ are target stimuli (stimulus which is appeared in the form of star, moon or circle on the screen and the examinee has to select it). The presentation time of each stimulus is 200 milliseconds and the interval between them is 1-second. After entering the personal information of the examinee in the profile section, the test is administered. Before the main test, the experimental (sample test) will be performed. At the beginning, necessary explanations are presented on the screen and the examiner should explain them for the examinee. The test gets started when the examinee is ready. The test time by considering the experimental test is entirely 200 seconds. According to the various forms and the obtained analyses of test, designed computerized CPT in this study is based on the comparison of response rate, commission, omission, reaction time and interference of participant's response $(5,6,15,36,59)$.

The computerized Stroop task was produced by Ridley Stroop in 1935 for the first time to measure selective attention and cognitive flexibility (50). This test has been used in different studies of various clinical groups to assess the ability of response inhibition, selective attention, cognitive variability and flexibility. It consists of two stages. In the first stage, color naming, the examinee is asked to discover the intended color of the appeared shape on the screen from among a determined collection of colors (red, blue, yellow and green). This stage purpose is just training and familiarizing the colors and places of keys on the keyboard which has no impact on the final result. The second stage is the main Stroop test performance. At this stage, 48 congruent and 48 incongruent colorful words are shown randomly and consecutively to the examinee in red, blue, yellow and green. Congruence is referred to the words which are similar in color and meaning in Persian language, for instance the word blue which has a blue color too. Congruent words are those which their color and meaning is different, for example the word green which is displayed in red, blue or yellow. The task of examinee is to find out the apparent color regardless of the word's meaning. The presentation time of each stimulus on the screen is 2 seconds and the interval between each presentation is 800 milliseconds. Researchers believe that the color-word task (the second stage) can assess mental flexibility, interference and response inhibition (62). The interference measure will be obtained by subtracting the number of correct incongruent score from the score of correct congruent words. Here, a circle shape is shown for the examinee in red, yellow, green and blue consecutively. They have to press the defined keys to determine the correct color by maximum speed. Congruent and incongruent error (error01 and erroe02), congruent and incongruent Time reaction (timerec01 and timrec02) and
Result tests of the participants are the investigating measures of the Stroop test.

The ability of planning in order to predict events and monitoring to access the goal in most problem solving activities is known as a main cognitive component. The Tower of London task was first introduced by Shallice in 1982 (24). This task has been developed to evaluate at least two aspects of problem solving and executive actions which means strategic planning. Recently, researchers have tried to apply this test in assessing dysfunction of the frontal lobe in different clinical populations including Parkinson's disease, depression, schizophrenia, Huntington's chorea disease, failure attention deficits with hyperactivity, learning disorder, autism, hydrocephalus and other diseases such as brain tumor (51). After entering the personal information of the examinee in the profile section, the test starts. During the test, the sample should get fixed with minimum necessary movements by moving the color pages (green, blue and red) and putting them in the right place. It should be noted that only the upper pages can be moved and in long column 3 pages, in the middle column 2 pages and in short column 1-page can be placed. Then, the examinee is asked to solve the example. The examinee is permitted to solve the problem in 3 tries and $\mathrm{s} /$ he has to follow the instructions with minimal necessary movements. After each stage of success (and if after three attempts, the problem is still not resolved) the next stage will be given to the examinee. The computerized TOL test is based on comparison of Time test, Time late, Time total, Result, Error, reaction time and Response interference measures.

\section{Statistical analysis}

It is hypothesized that the neuro-cognitive tests of CPT, Stroop and TOL could assess and diagnose attention and executive functions of brain tumor patients and the healthy group for the study's goal. In doing so, a comparative assessment of all three test's variables was initially done separately on both 2 groups. Spearman correlation tables with significance level of 0.05 were used for this purpose and the corresponding P-value amounts were examined. Then, the tests were reviewed. By using the Fischer test, in the case that the samples were independent of one another the P-value amount of each sample was gained. Statistical analysis was performed with the SPSS 18 software. As the tables suggest in the results, the healthy subjects and brain tumor patients differ more significantly from one another in age, sex and education than the rest of variables.

\section{RESULTS}

Descriptive statistics for both 2 groups of brain tumor patients and healthy ones who performed the neuro-cognitive tests, CPT, Stroop and TOL are presented in 3 separate tables. These were analyzed through Pearson correlation coefficient and t-test statistical methods. At first, the variables which may affect the performance of these three tests were determined, including age, sex and education. 
Data presented in Table I indicate there was a significant difference $(p<0.05)$ in all measures of the CPT test between brain tumor patients and healthy participants in the whole age groups of the study. In other words, brain tumor patients face more sustained attention impairments than healthy ones in all age groups.

A significant difference $(p<0.05)$ was also observed between brain tumor patients and healthy participants with any educational degree for the education variable in all measures of the CPT test. It means that in all educational levels, patients with brain tumor have more sustained attention impairments than healthy participants.

Considering the equal number of males and females in both groups of healthy and patients, it should be noted that sex variable was not an important factor in distinguishing sustained attention difference. As a result, the sustained attention scale was alike in both sexes (Table II).

Similar to the previous table, performance of the Stroop test in all measures was significantly different $(p<0.05)$ among patients and healthy participants in all age groups. Based on the education variable, the only exception in which the difference of test's performance of both groups was not significant was the timerec02 measure (incongruent time reaction) (timerec02 $=6, p$-value $>0.05$ ). Therefore, brain tumor patients are confronted with more selective attention impairments than healthy participants in all age groups and educational levels except in the mentioned measure.

The row related to sex variable shows there is no significant difference between males and females in both groups of healthy and patients due to the equal number of both sexes

The statistical results of TOL test are presented in Table III which indicates that at any age groups of patients and healthy participants with any kind of education level, the difference of both 2 groups of participant's performance was significant $(p<0.05)$ without any exception in any measures of the test. In other words, brain tumor patients in all age groups and with any education levels had more impairment in planning ability than healthy ones.

Regarding the sex variable, as mentioned before, the number of males and females was equal in both groups of healthy and patients. Consequently, there was no significant difference between these 2 groups and they did not differ in planning ability scale. It is clear that this variable is not considered as an important factor in showing the different performance of the groups.

\section{DISCUSSION}

The hypothesis of this investigation was to confirm the role and the impact of neuro-cognitive tests in diagnosing and assessing sustained, selective attention and planning of brain tumor patients. It can therefore be concluded that the aim of the study was accomplished through the current findings. The performance of brain tumor patients was compared with healthy participants for various measures of CPT, Stroop and TOL tests. It showed a significant difference $(p<0.05)$ to a great extent. With regard to different aspects of attention and executive functions, sustained, selective attention and planning were evaluated through CPT, Stroop and TOL tests respectively. According to the obtained results, these cognitive impairments were more observed among brain tumor patients than healthy ones which can prove the diagnostic role of the neuro-cognitive tests. In situations where error reduction, speed and efficiency are considered, these tests can be well used (11). It is also worth noting that these neurocognitive tests are applied as a sensitive tool for vast range of clinical conditions relevant to cognitive impairments (17). The statistical and quantitative analyses indicate that the diagnostic criteria of these tests are verified with an acceptable percentage of the patients with brain tumor (66). Previous researches also have approved that having this kind of impairments make these patients disabled to learn and adjust to the environment, workplace and community condition in contrast to healthy participants (12). Reviewing different cognitive aspects can help better understanding of the involving factors in creating problems for these patients. The mentioned impairments can lead to failure in maintaining job opportunities for brain tumor patients. Developing dependence to others in performing basic activities at workplace and even daily personal ones is another problem $(2,3,7)$. Attention impairments and executive dysfunctions still are considered as the most common complaints among patients with brain tumor. Finding these impairments in cognitive domains of brain tumor patients represents that the current study is in line with previous ones $(46,49)$. In studies including cognitive reviews, existence of attention and planning impairments have been affirmed in patients with brain tumor. It shows the variation of attention impairments level, the induced executive function related to the disease, treatment factors and also assessment tools $(10,18)$. Based on some studies, despite the treatments provided, attention and planning impairments still exist among brain tumor patients and these treatments were not effective in reducing the problems. They even occasionally led to worsening of the cognitive performance in brain tumor patients $(21,22,26,54)$. Several researches point to the rehabilitation role through other neural techniques (67). Finally, additional evidences can be derived from all these surveys for the purpose of diagnosing and assessing the aforementioned impairments of brain tumors. These findings along with a clarified diagnosis of impairments present in brain tumor patients can assist in therapeutic recommendations. It also leads further researches into greater guidelines of this issue (16).

The current study exhibited that the cognitive impairments of patients with brain tumor are approved with the new cognitive tests. It is suggested that the future comparisons with various mental and cognitive tests prior and after the treatment and rehabilitation can have a substantial role in promotion of treatment, survival and life quality among these patients. 


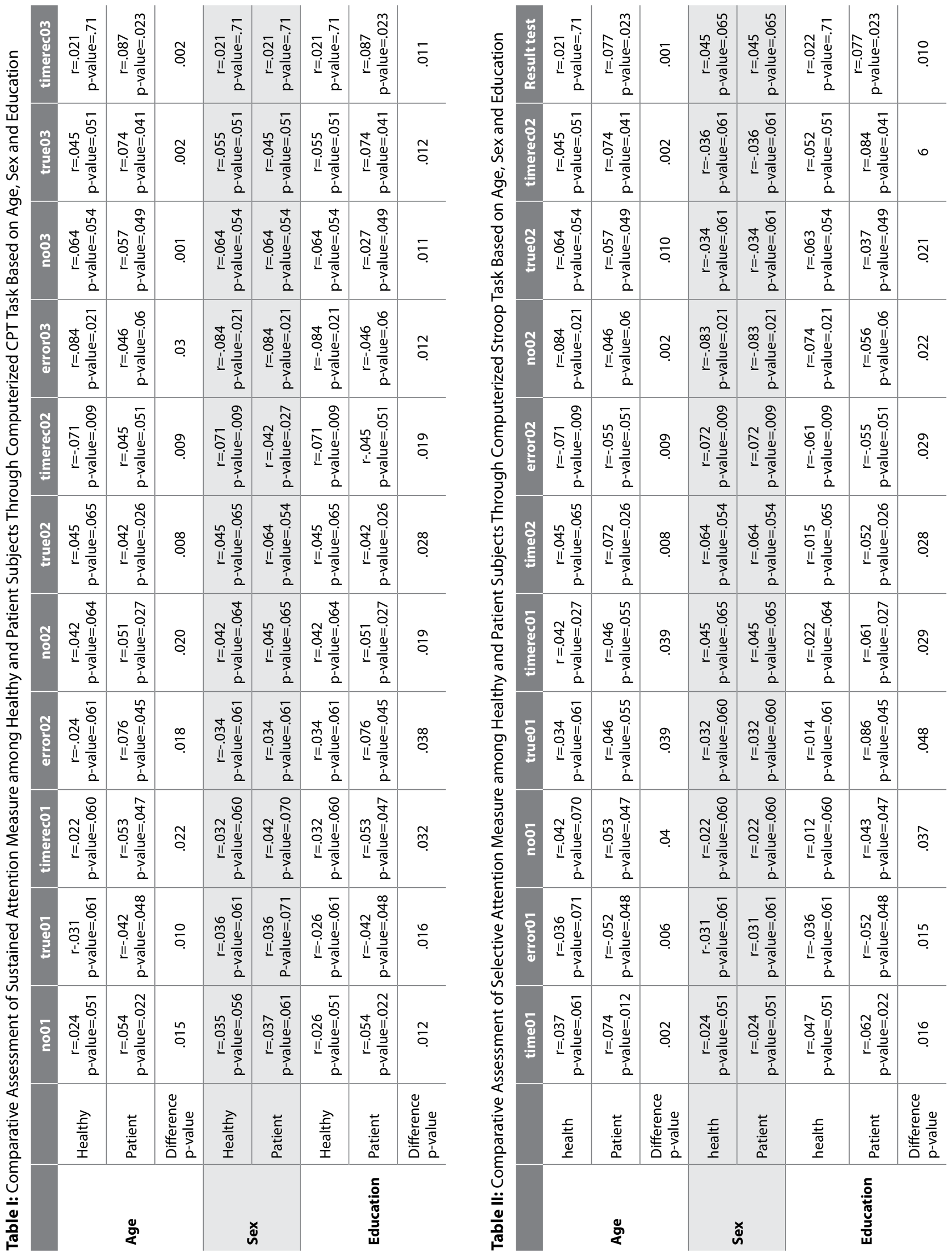


Table III: Comparative Assessment of Planning Measure among Healthy and Patient Subjects Through Computerized TOL Task Based on Age, Sex and Education

\begin{tabular}{|c|c|c|c|c|c|c|}
\hline & & Time test & Time late & Time total & Error & Result \\
\hline \multirow{3}{*}{ Age } & healthy & $\begin{array}{c}r=.074 \\
p-\text { value }=.009\end{array}$ & $\begin{array}{c}r=.087 \\
p-\text { value }=.021\end{array}$ & $\begin{array}{c}r=.065 \\
p-\text { value }=.054\end{array}$ & $\begin{array}{c}r=-.054 \\
p \text {-value }=.051\end{array}$ & $\begin{array}{c}r=.022 \\
p \text {-value }=.71\end{array}$ \\
\hline & Patient & $\begin{array}{c}r=.045 \\
p \text {-value }=.051\end{array}$ & $\begin{array}{c}r=.046 \\
p \text {-value }=.06\end{array}$ & $\begin{array}{c}r=.027 \\
p-\text { value }=.049\end{array}$ & $\begin{array}{c}r=-.084 \\
p \text {-value }=.041\end{array}$ & $\begin{array}{c}r=.081 \\
p \text {-value }=.023\end{array}$ \\
\hline & Difference $p$-value & .009 & .011 & .010 & .009 & .011 \\
\hline \multirow{2}{*}{ Sex } & healthy & $\begin{array}{c}r=.036 \\
p \text {-value }=.061\end{array}$ & $\begin{array}{c}r=.087 \\
p \text {-value }=.021\end{array}$ & $\begin{array}{c}r=-.064 \\
p-\text { value }=.010\end{array}$ & $\begin{array}{c}r=.015 \\
p \text {-value }=.065\end{array}$ & $\begin{array}{c}r=.014 \\
p \text {-value }=.061\end{array}$ \\
\hline & Patient & $\begin{array}{c}r=.036 \\
p \text {-value }=.061\end{array}$ & $\begin{array}{c}r=.087 \\
p-v a l u e=.021\end{array}$ & $\begin{array}{c}r=-.064 \\
p \text {-value }=.010\end{array}$ & $\begin{array}{c}r=.015 \\
p \text {-value }=.065\end{array}$ & $\begin{array}{c}r=.014 \\
p \text {-value }=.061\end{array}$ \\
\hline \multirow{3}{*}{ Education } & healthy & $\begin{array}{c}r=.015 \\
p \text {-value }=.065\end{array}$ & $\begin{array}{c}r=.074 \\
p \text {-value }=.009\end{array}$ & $\begin{array}{c}r=.089 \\
p \text {-value }=.021\end{array}$ & $\begin{array}{c}r=-.064 \\
p \text {-value }=.054\end{array}$ & $\begin{array}{c}r=.059 \\
p \text {-value }=.051\end{array}$ \\
\hline & Patient & $\begin{array}{c}r=.072 \\
p \text {-value }=.026\end{array}$ & $\begin{array}{c}r=.025 \\
p \text {-value }=.051\end{array}$ & $\begin{array}{c}r=.046 \\
p \text {-value }=.06\end{array}$ & $\begin{array}{c}r=-.027 \\
p-\text { value }=.049\end{array}$ & $\begin{array}{c}r=.071 \\
p \text {-value }=.041\end{array}$ \\
\hline & Difference $p$-value & .028 & .019 & .012 & .011 & .012 \\
\hline
\end{tabular}

\section{REFERENCES}

1. Aman CJ, Roberts RJ Jr, Pennington BF: A neuropsychological examination of the underlying deficit in attention deficit hyperactivity disorder: Frontal lobe versus right parietal lobe theories. Dev Psychol 34(5):956-969, 1998

2. Anderson SW, Damasio H, Tranel D: Neuropsychological impairments associated with lesions caused by tumor or stroke. Arch Neurol 47:397-405, 1990

3. Archibald YM, Lunn D, Ruttan LA, Macdonald DR, Del Maestro RF, Barr HW, Pexman JH, Fisher BJ, Gaspar LE, Cairncross JG: Cognotive functioning in long term survivors of high grade glioma. J Neurosurg 80:247-253, 1994

4. Armstrong FD, Blumberg MJ, Toledano SR: Neurobehavioral issues in childhood cancer. School Psychol Quarterly 28: 194-203, 1999

5. Barkley RA: A new theory of ADHD. The ADHD Report 1(1): 1-4, 1993

6. Beck LH, Bransome ED Jr, Mirsky AF, Rosvold HE, Sarason I: A continuous performance test of brain damage. J Consult Psychol 20(5):343-350, 1956

7. Bosma I, Reijneveld JC, Klein M, Douw L, Van Dijk BW, Heimans JJ, Stam CJ: Disturbed functional brain networks and neurocognitive function in low grade glioma patients: A graph theoretical analysis of resting state MEG. Nonlinear Biomed Phys 3(1):9, 2009

8. Brewis A: Social and biological measures of hyperactivity and inattention: Are they describing similar underlying constructs of child behavior? Soc Biol 49(1-2): 99-115, 2002

9. Carlson $\mathrm{CL}$, Lahey $\mathrm{BB}$, Neeper R: Direct assessment of the cognitive correlates of attention deficit disorders with and without hyperactivity. Journal of Behavioural Assessment and Psychopathology 8:69-86, 1986

10. Correa DD, DeAngelis LM, Shi W, Thaler H, Glass A, Abrey LE: Cognitive functions in survivors of primary central nervous system lymphoma. Neurology 62(4):548-555, 2004
11. Culberston WC, Zillmer EA: Tower of London performance in children and adolescents: Relationships to neuropsychological measures of frontal lobe functioning. Arch Clin Neuropsychol 5:314, 1995

12. Divcić B, Hajnzić TF: Neuropsychological functioning of children with brain tumors. Acta Clin Croat 47(2):67-75, 2008

13. Fallgatter AJ, Ehlis AC, Seifert J, Strik WK, Scheuerpflug $P$, Zillessen KE, Herrmann MJ, Warnke A: Altered response control and anterior cingulate function in attention-deficit/ hyperactivity disorder boys. Clin Neurophysiol 115(4): 973-981, 2004

14. Fisher JL, Schwartzbaum JA, Wrench M, Wiemels JL: Epidemiology of brain tumors. Neurol Clin 25(4):867-890, 2007

15. Garretson HB, Fein D, Waterhouse L: Sustained attention in children with autism. J Autism Dev Disord 20(1):101-114, 1990

16. Ghaziuddin M, Tsai L, Alessi N: ADHD and PDD. J Am Acad Child Adolesc Psychiatry 31(3):567, 1992

17. Gualtieri CT, Johnson LG: Reliability and validity of a computerized neurocognitive test battery, CNS Vital Signs. Arch Clin Neuropsychol 21(7):623-643, 2006

18. Harder $\mathrm{H}$, Holtel $\mathrm{H}$, Bromberg JE, Poortmans $\mathrm{P}$, HaaxmaReiche $\mathrm{H}$, Kluin-Nelemans $\mathrm{HC}$, Menten J, van den Bent MJ: Cognitive status and quality of life after treatment for primary CNS lymphoma. Neurology 62(4):544-547, 2004

19. Haupt R, Fears TR, Robison LL, Mills JL, Nicholson HS, Zeltzer LK, Meadows AT, Byrne J: Educational attainment in longterm survivors of childhood acute lymphoblastic leukemia. JAMA 272(18):1427-1432, 1994

20. Kaplan CP and Miner ME: Relationships: Importance for patients with cerebral tumors. Brain Inj 14(3):251-259, 2000

21. Kayl $A E$, Meyers $C A$ : Does brain tumor histology influence cognitive function? Neuro Oncol 5:255-260, 2003 
22. Klein M, Heimans JJ, Aaronson NK, van der Ploeg HM, Grit J, Muller M, Postma TJ, Mooij JJ, Boerman RH, Beute GN, Ossenkoppele GJ, van Imhoff GW, Dekker AW, Jolles J, Slotman BJ, Struikmans H, Taphoorn MJ: Effect of radiotherapy and other treatment related factors on midterm to long term cognitive sequelae in low grade gliomas: A comparative study. Lancet 360:1361-1368, 2002

23. Landis SH, Murray T, Bolden S, Wingo PA: Cancer statistics, 1999. CA Cancer J Clin 49(1):8-31, 1, 1999

24. Lange KW, Robbins TW, Marsden CD, James M, Owen AM, Paul GM: L-dopa withdrawal in Parkinson's disease selectively impairs cognitive performance in tests sensitive to frontal lobe dysfunction. Psychopharmacology (Berl) 107(2-3): 394-404, 1992

25. Losier BJ, McGrath PJ, Klein RM: Error patterns on the continuous performance test in non-medicated and medicated samples of children with and without ADHD: A meta-analytic review. J Child Psychol Psychiatry 37(8): 971-987, 1996

26. Lupien SJ, Gillin CJ, Hauger RL: Working memory is more sensitive than declarative memory to the acute effects of corticosteroids: A dose response study in humans. Behav Neurosci 113:420-430, 1999

27. Luria A:The working brain. London: Penguin, 1973

28. Mabbott DJ, Penkman L, Witol A, Strother D, Bouffet E: Core neurocognitive functions in children treated for posterior fossa tumors. Neuropsycholog 22(2):159-168, 2008

29. Meyers CA, Hess KR, Yung WK, Levin VA: Cognitive function as a predictor of survival in patients with recurrent malignant glioma. J Clin Oncol 18:646-650, 2000

30. Mostow EN, Byrne J, Connelly RR, Mulvihill JJ: Quality of life in long-term survivors of CNS tumors of childhood and adolescence. J Clin Oncol 9(4):592-599, 1991

31. Nigg JT, Hinshaw SP, Carte ET, Treuting JJ: Neuropsychological correlates of childhood attention-deficit/hyperactivity disorder: Explainable by comorbid disruptive behavior or reading problems? J Abnorm Psychol 107(3):468-480, 1998

32. Okazaki S, Maekawa H, Futakami S: Control of response inhibition in children with ADHD on the CPT under various intervals, Jpn J Spec Educ 38:97-103, 2001

33. Okazaki S, Hosokawa M, Kawakubo Y, Ozaki H, Maekawa H, Futakami S: Developmental change of neurocognitive motor behavior in a continuous performance test with different interstimulus intervals. Clin Neurophysiol 115(5):1104-1113, 2004

34. Owen AM, Downes JJ, Sahakian BJ, Polkey CE, Robbins TW: Planning and spatial working memory following frontal lobe lesions in man. Neuropsychologia 28(10):1021-1034, 1990

35. Papazoglou A, King TZ, Morris RD, Krawiecki NS: Cognitive predictors of adaptive functioning vary according to pediatric brain tumor location. Dev Neuropsychol 33(4):505-520, 2008

36. Pascualvaca DM, Fantie BD, Papageorgiou M, Mirsky AF: Attentional capacities in children with autism: Is there a general deficit in shifting focus? J Autism Dev Disord 28(6): 467-478, 1998
37. Passik S, Ricketts PL: Central nervous system tumors. In Psycho-oncology, Holland JC ed. New York: Oxford Press, 1998: 303-313

38. Pennington BF, Ozonoff S: Executive functions and developmental psychopathology, J. Child Psychol Psychiatry 37: 51-87, 1996

39. Reeve WV, Schandler SL: Frontal lobe functioning in adolescents with attention deficit hyperactivity disorder. Adolescence 36(144):749-765, 2001

40. Riccio CA, Reynolds CR, Lowe P, Moore JJ: The continuous performance test: A window on the neural substrates for attention? Arch Clin Neuropsychol 17(3):235-272, 2002

41. Ris D, Noll RB: Long-term neurobehavioral outcome in pediatric brain tumor patients: Review and methodological critique. J Clin Exper Neuropsychol 16:21-42, 1994

42. Robbins TW, James M, Lange KW, Owen AM, Quinn NP, Marsden CD: Cognitive performance in multiple system atrophy. Brain 115(1):271-291, 1992

43. Roman DD, Sperduto PW: Neuropsychological effect of cranial irradiation: Current knowledge and future directions. Int J Radiat Oncol Biol Physics 31:983-998, 1995

44. Schachar R, Tannock R, Marriott M, Logan G: Deficient inhibitory control in attention deficit hyperactivity disorder. J Abnorm Child Psychol 23(4):411-437, 1995

45. Shallice T: Specific impairments of planning. Philos Trans $R$ Soc Lond B Biol Sci 298(1089):199-209, 1982

46. Siegel BV Jr, Nuechterlein KH, Abel L, Wu JC, Buchsbaum MS: Glucose metabolic correlates of continuous performance test performance in adults with a history of infantile autism, schizophrenics, and controls. Schizophr Res 17(1):85-94, 1995

47. Spitzer RL: Values and assumptions in the development of DSM-III and DSM-III-R: An insider's perspective and a belated response to Sadler, Hulgus, and Agich's "On values in recent American psychiatric classification". J Nerv Ment Dis 189(6): 351-389, 2001

48. Spreen O, Strauss E: A compendium of neuropsychological tests: Adminsitration, norms, and commentary, 2nd ed. New York: Oxford University Press, 1998

49. Strandburg RJ, Marsh JT, Brown WS, Asarnow RF, Guthrie D, Higa J: Event-related potentials in high-functioning adult autistics: Linguistic and nonlinguistic visual information processing tasks. Neuropsychologia 31(5):413-434, 1993

50. Stroop JP: Studies of interference in serial verbal reactions. Journal of Experimental Psychology 18:643-662, 1935

51. Sturm H, Fernell E, Gillberg C: Autism spectrum disorders in children with normal intellectual levels: Associated impairments and subgroups. Dev Med Child Neurol 46(7): 444-447, 2004

52. Stuss DT, Floden D, Alexander MP, Levine B, Katz D: Stroop performance in focal lesion patients: Dissociation of processes and frontal lobe lesion location. Neuropsychologia 39:771-786, 2001

53. Tannock R, Martinussen R, Frijters J: Naming speed performance and stimulant effects indicate effortful, semantic processing deficits in attention-deficit/hyperactivity disorder. J Abnorm Child Psychol 28(3):237-252, 2000 
54. Van Breemen MSM, Wilms EB, Vecht CJ: Epilepsy in patients with brain tumors: Epidemiology, mechanisms, and management. Lancet Neurol 6:421-430, 2007

55. van Leeuwen $\mathrm{TH}$, Steinhausen $\mathrm{HC}$, Overtoom CC, PascualMarqui RD, van't Klooster B, Rothenberger A, Sergeant JA, Brandeis D: The continuous performance test revisited with neuroelectric mapping: Impaired orienting in children with attention deficits. Behav Brain Res 94(1):97-110, 1998

56. Verbaten MN, Overtoom CC, Koelega HS, Swaab-Barneveld H, van der Gaag RJ, Buitelaar J, van Engeland H: Methylphenidate influences on both early and late ERP waves of ADHD children in a continuous performance test. J Abnorm Child Psychol 22(5):561-578, 1994

57. Waber DP, Carpentieri SC, Klar N, Silverman LB, Schwenn M, Hurwitz CA, Mullenix PJ, Tarbell NJ, Sallan SE: Cognitive sequelae in children treated for acute lymphoblastic leukemia with dexamethasone or prednisone. J Pediatr Hematol Oncol 22(3):206-213, 2000

58. Walsh K: Neuropsychology, clinical approach Zud ed. New York: Churchill Living Stone, 1987

59. Warm JS: Sustain Attention in Human Performance. New York: John Wiley \& Sons, 1984:1-14

60. Warschausky S, Kewman D, Kay J: Empirically supported psychological and behavioral therapies in pediatric rehabilitation of TBI. J Head Trauma Rehabil 14(4):373-383, 1999
61. Watts FN, MacLeod AK, Morris L: Associations between phenomenal and objective aspects of concentration problems in depressed patients. Br J Psychol 79(Pt 2):241-250, 1988

62. Wecker NS, Kramer JH, Wisniewski A, Delis DC, Kaplan E: Age effects on executive ability. Neuropsychology 14(3):409-414, 2000

63. Wen PY, Kesari S: Malignant gliomas in adults. N Engl J 359(5): 492-507, 2008

64. Willcutt EG, Pennington BF, Boada R, Ogline JS, Tunick RA, Chhabildas NA, Olson RK: A comparison of the cognitive deficits in reading disability and attention-deficit/ hyperactivity disorder. J Abnorm Psychol 110(1):157-172, 2001

65. Wrensch M, Minn Y, Chew T, Bondy M, Berger MS: Epidemiology of primary brain tumors: Current concepts and review of the literature. Neuro Oncol 4(4):278-299, 2002

66. Yoshida $\mathrm{Y}$, Uchiyama T: The clinical necessity for assessing Attention Deficit/Hyperactivity Disorder (AD/HD) symptoms in children with high-functioning Pervasive Developmental Disorder (PDD). Eur Child Adolesc Psychiatry 13(5):307-314, 2004

67. Zahmacioglu O, Dinc G, Naderi S:The history of psychosurgery in Turkey. Turk Neurosurg 19(3):308-314, 2009 